\title{
REVIEW PAPER: THE MEDIATING ROLE OF CREATIVITY ON THE RELATIONSHIP BETWEEN KNOWLEDGE MANAGEMENT AND HUMAN RESOURCE MANAGEMENT TOWARD INNOVATION PERFORMANCE IN THE JORDANIAN SMES
}

\author{
Ahmed Mohammed Abdulaal1,* and Norfarah Nordin ${ }^{1}$ \\ ${ }^{1}$ Graduate School of Business, Universiti Sains Malaysia, Penang, Malaysia.
}

ABSTRACT -This study aims to review around 100 previous studies in the SMEs in Jordan. The economic revolution at the current moment is relying on the SMEs industry to handle the crucial business in the countries. The main concern of this study is the innovation performance in the SMEs in Jordan, which is a need to compete in the current competitive business world nowadays. This study found the innovation performance is needed in the SMEs in Jordan. The study found human resource management, knowledge management, and creativity are among the variables that must be included toward the prosperity of the industry to be able to assist the country's economy. Moreover, there is a relationship found between activating the role of human resource management on the intellectual capital, creativity, and innovation in the Jordanian SMEs.

\author{
ARTICLE HISTORY \\ Received:15-9-2020 \\ Accepted:1-12-2020
}

\section{KEYWORDS}

Innovation Performance, Human Resource

Management, Knowledge Management

\section{INTRODUCTION}

Innovation is widely believed to be a key factor in economic growth (Shujahat et al., 2019), especially in developing countries (Crespi, Tacsir, \& Zuniga, 2011; Jiménez \& Zheng, 2018). It is crucially important to understand the determinants of innovation at the country level as well as to identify the development stages of innovation (Tidd \& Bessant, 2018). Today's business environment believed that human resource management is providing organizations with the competitive advantage and strength they need to achieve profitability, productivity, efficiency, effectiveness, and pioneering the market (Noe et al., 2017). Human resource practices approved by the researchers and scientists as the main supportive source for the organizational competitiveness and human resource management is a concern because it is the flexible forces in the organization that could make the difference (Melhem, 2019).

Thus, human resource is the source of knowledge while knowledge is considered as a firm's source of strength and power. There has been a lot of changes in the understanding of KM and HRM, particularly from the perspective of an organization's plan and strategies to share knowledge between employees in the organizations (Hisschemöller et al., 2018).

The private economy in Jordan is comprised almost entirely of SMEs. Most Jordanian SMEs work within the formal sector and are registered as required by the law (Roman, 2017). Formal SMEs play a significant role in employment, as they employ approximately $71.4 \%$ of the private sector's workforce and almost $49.4 \%$ of all the personnel in the country's private and public sectors (Assaad \& Amer, 2008; Assaad et al., 2018a; Assaad et al., 2018b). Thus, Jordanian SMEs play a critical role in helping to expand the country's economy. Innovation is a critical success factor that boosts the performance of many organizations throughout the world. The reviewed issues in this paper embodied the decrease of the GDP in Jordan from 5,600 in 2015 to 4,156 in 2019 due to the conflicts in the surrounding countries, adding the unemployment continuous increasing rate to reach $16.10 \%$ in 2019 , while the Jordanian government announced the need for SMEs support (Betz \& Frewer, 2016). Regardless, a huge number of SMEs were reported to have poor innovation performance and lack of well-used knowledge and human resource management (Al-Dwairi, Al-Tweit, \& Zyout, 2018). Lack of knowledgeable human resources in Jordan is expected to impact innovation performance in the country (Alshanty et al., 2019). Roman (2017) stated that there is a presence of poor implication of human resource practices and activate knowledge base development in the country.

\section{LITERATURE REVIEW}

The implementation of IP in the organization is a perspective of improving the HRM and employee retention in the organizations (Papa et al., 2018). While IP is an approach of HRM practices and one of their advantages (Diaz-Fernandez, Pasamar-Reyes, \& Valle-Cabrera, 2017), HRM is the base source of KM leading to IP (Vaziri, \&farhadi, 2018). Innovation could be described as the specific tool and technique by exploiting changes and opportunities for a different business, creating and introducing something new, novel, or advanced with the intention of creating value or benefit (Kearney and Hisrich, 2014).

In the previous studies, Baccarella et al. (2018), and Frederiksen and Knudsen (2017) stated that discussing and accomplishing the IP was recommended as an essential variable in creativity, which was justified as the first step and 
provider of IP in the organizations. In the working environment, the creativity of an individual enhances the IP of the whole organization (Khalili, 2016). These studies supported this finding to examine the effect of KM and HRM on IP while this relationship will be mediated by creativity. According to the previous studies, it was mentioned above the betterment of the model embodied in studying such group of variables to find out useful results in SMEs in Jordan. In the current fast-paced competitive globalized marketplace, innovation has become almost a prerequisite for business success (Santos et al., 2018).

\section{Innovation Performance}

In economics, Joseph Schumpeter was the one who introduced this concept in his "theory of innovations," (Anthony et al., 2008), in which he defines it as the establishment of a new production function. The economy and society change when the factors of production are combined in a novel way.

Marketing innovation is developing new techniques, methods, and tools for marketing which is significant to rule the success of the organizations, such as changing ways for collecting customer's information. Firms are now using computer software to collect customer information, new formats of trading such as online store which is also an example of marketing innovation (Li \& Chen, 2006). Marketing innovations target at addressing customer needs better, opening up new markets, or newly positioning a firm's product on the market with the intention of increasing firm's sales. This is strongly related to pricing strategies, product package design properties, product placement, and promotion activities along the lines of the four Ps of marketing (Grimpe et al., 2017).

Organizational innovation is comprehensive including all the organizational activities and practices (Azar \& Ciabuschi, 2017). The practices of innovation include sales, production, customer service, quality, and relations inside and outside the organization (Paula et al., 2016). This involves changing the structure of an organization into a different form to make it more cost-efficient and/or more suitable to exploit or serve market opportunities. As an example, A company moves from selling over-the-counter products and employing more staffs to operating online with fewer staffs (Shin, Jeong, \& Bae, 2018). It is evident that innovation shall be examined according to the business environment in terms of factors affecting it and further dimensions could play a turn (Demircioglu, 2017).

\section{Knowledge Management}

Malik, McKenna, and Plummer (2015) defined knowledge management as what the employees acquired during their lifetime as employees in terms of information, skills, and abilities to work in different environments and conditions according to the management requirements. Berger (2015) described it as a batch of values being practiced while the employee is doing his job and dealing with his colleagues.

The development of the scientific method has made a significant contribution to how knowledge of the physical world and its phenomena is acquired (Hassan \& Hussein, 2019). Monavvarian and Khamda (2010) described knowledge creation and suggested that employees are an essential source of knowledge creation.

Lai, Chen, and Chang (2014) concluded that the optimal factor to achieve the IP is through KM. It is found that knowledge creation, knowledge integration, and knowledge application facilitate innovation and performance (Ferraris, Santoro, \& Dezi, 2017). Soto-Acosta, Popa, and Palacios-Marqués, (2017) reported that all the aspects of KM are importantly presented in SMEs to improve the IP in the firms. Accordingly, the direct and significant relationship between $\mathrm{KM}$ and IP in the organizations is approved (Mardani, et al., 2018). Meanwhile, this study will examine it in the SMEs in Jordan.

\section{Human Resource Management}

HRM is the development of creativity in organizations which is relying on consistent and stable activities, developing the organizational members, and implementing the policies of the organization (Armstrong \& Taylor, 2020). The target of developing a human resource structure is to improve the total organizational performance in terms of skills, knowledge, and adaption abilities (Mohammed \& Hassanain, 2010). This study summarizes the most important tasks of HRM as follows: Human resource management practices (Subramaniam et al., 2016).

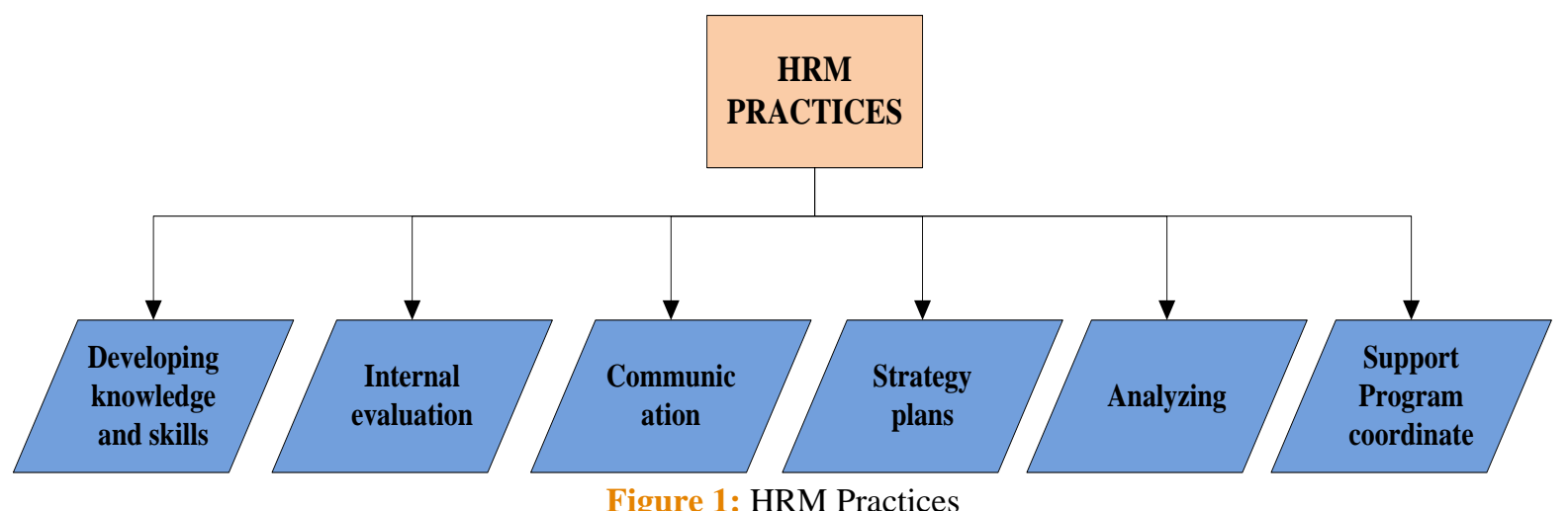


HRM practices are management functions. Recently, the organizations are targeting the department of human resources to improve productivity and quality of the goods through the higher achieved performance (Wikhamn, 2019). Training is one of the main practices in the firms toward total improvement such as maintaining market superiority, enhancing staff skills and knowledge, and increasing productivity (Habib, Zahra, \& Mushtaq, 2015). One of the most widespread ways to enhance individual productivity within an organization is by achieving organizational goals and improving staff skills and performance (Liu \& Lu, 2016).

Furthermore, the recruitment process could indicate that the programs are concerned with selecting persons for unpaid posts, such as the unpaid trainee role or the voluntary role (Chang \& Chin, 2018). The recruitment and selection process is considered as a very vital and important activity. As one of the human resource management functions, it positively influences the organization's performance, particularly in realizing its eventual and ultimate goals and targets (Njoku et al., 2019).

\section{Creativity}

Traditionally, there was little research on the creativity of dominant psychology (Henriksen, 2019), but there were also research in other sciences, including the theory of organization (Saether, 2019). It also provides a foundation for understanding the emergence of new businesses (Bocken, Boons, \& Balldassare, 2019). Creativity research tends to cluster around four perspectives: trait (person), individual, process, and product. Conceptualizing creativity as a process constitutes a field in which this process takes place and empowers the individual to be creative (Puhakka, 2012).

The study of creativity was often aimed at identifying the most creative people or teams to improve the social situation (Mellander \& Florida, 2011). In addition, the environment can be perceived as a source of stimulation (Tubbs \& Moss, 2002). In fact, the analysis of a trait, a process, or a product must also take into account who is being evaluated, by whom, and according to which methodology.

Process innovation concerns more about organization innovation, as detailed as individuals, systems, and operation innovation (Comunian, Gilmore, \& Jacobi, 2015). Illustrating the verifications, exploring, and implementing the required and proper process needs creativity (Sadler-Smith, 2015).

\section{SMEs Industry in Jordan}

The middle east countries lately are concerned with SMEs. Jordan was among the countries that worked hard to activate the economical practice, facing obstacles in the Jordanian environment such as economic, political, and legal aspects (Camra-Fierro et al., 2012). With the decrease of the GDP in Jordan from 5,600 in 2015 to 4,156 in 2019 due to the conflicts in the surrounding countries, adding the unemployment continuous increasing rate to reach $16.10 \%$ in 2019 , the country now needs the SMEs industry to be more effective and contribute in the country's development (Betz \& Frewer, 2016). The Jordanian government needs the private sector support with the intention to fund the private sector to improve their activities and contribute further in the economic activities especially the SMEs sector (Betz \&Frewer, 2016). The SMEs in Jordan are using general and traditional managerial strategies which cause poor organizational performance (Al Tawara \& Gide 2017). Thus, SMEs accounted for $99.4 \%$ of Jordan's 156,000 enterprises, and 70\% of the workforce (Al-Dwairi, Al-Tweit, \& Zyout, 2018).

Jordanian industries are required to have an innovation base and knowledge infrastructure (Hajir et al., 2015), and this is reflected in the financial performance as well as other variables such as knowledge and human resource management (Migdadi et al., 2017). There is an issue reported in the implications of the human resource management in the SMEs in Jordan as mentioned by Roman (2017). He stated that the implication of human resource in Jordan is critical and is discussed either in the context of human resource management or electronic human resource practices in Jordanian service SMEs.

Therefore, the importance of HRM is justified as the source of power to the Jordanian SMEs, as well as providing creative and innovative notions to the firms. Thus, this could call the knowledge capital of the firm represented by the human capital (Alshanty et al., 2019; Al-Hyari, 2013). The source of knowledge has a positive impact on the creativity of a firm, which leads the firms toward an economic revolution in the country (Malkawi \& Abu, 2016). This study will examine the innovation performance of Jordanian SMEs through the anticipated effect of the variables (knowledge, HRM), and this relationship is mediated by creativity.

\section{Study's Framework}

Referring to the previous literature and supportive studies, this study suggested this framework be studied, analyzed, and tested in the Jordanian SMEs. The framework structure was based on the literature and underpinning theories, which the logic of resource-based theory RBV papers suggested that only RBV resources matter in explaining sustained competitive advantage. However, we will argue that firm ability that is not necessarily rare, imitable, or inherently valuable can also explain performance variation (Bromiley \& Rau 2016). Theoretical foundations from the RBVF helped to guide the study. Innovation through products and processes (entrepreneurial) for cost efficiency and intellectual capital gained from employees among others. It is through these three perspectives (social capital, entrepreneurship, and intellectual capital) that the current inquiry is directed. An analysis of empirical research regarding the RBT noted that firm capabilities or resources were the primary drivers of explaining outcomes of performance (Campbell \& Park, 2017).

Innovation theory supporting the model of the study stated innovation as an idea, practice, or object perceived as new by the individual and discovery that goes no further than the laboratory remains an invention (Franceschinis et al., 2017). Small and medium-sized enterprises (SMEs) are considered the engine of innovation and their role in world economies 
are increasingly seen as fundamental, as most economic structures are mainly composed of SMEs (Hoffman et al., 1998). Moreover, there is strong evidence of how SMEs in a wide variety of sectors do engage in technological innovations, and these innovations are likely to be an important determinant of their success (Hoffman et al., 1998). They are certainly active in innovation development and they have the capacity for going radical and new to the world innovation (Acs \& Audretsch, 1987).

This framework will improve the innovativeness of the SMEs' performance in Jordan by practicing the concepts of creativity, human resource management, and knowledge management in the industry.

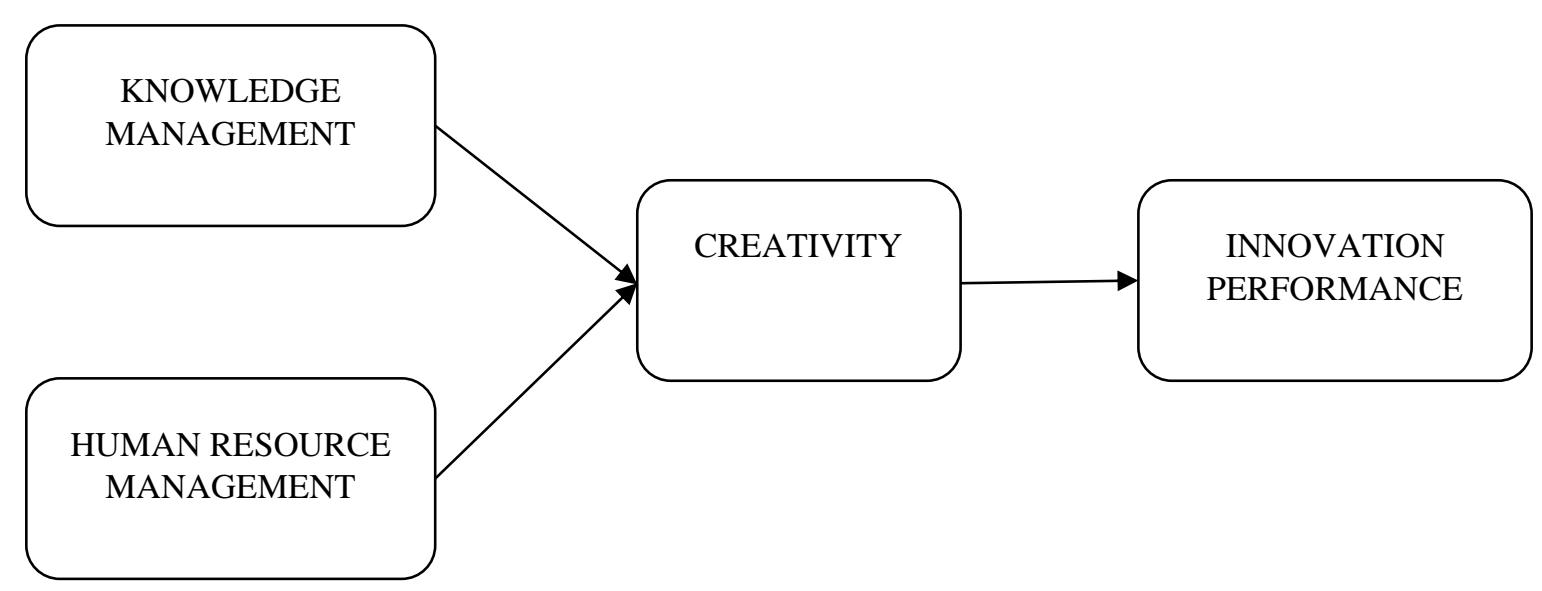

Figure 2: Conceptual Framework

\section{METHODOLOGY}

This research paper reviewed the relevant literature on organizational performance, human resource management, knowledge management, and creativity. The researcher reviewed up to 100 papers related to the keywords of this study. Comparing the findings of the papers and the different perspectives according to the industries of the study and the factors of the framework, it was found that there was a difference in the results.

The researcher used some annual and official government reports, such as The Higher Council for Science and Technology of Jordan report, The World Bank report, the 2014 Doing Business Report, statistics department of Jordan. These sources supported the data and figures of the study to establish the framework of the study according to the data reported in these reports.

\section{FINDINGS AND DISCUSSION}

The researchers reviewed 100 papers approximately to find out the discussion and different views of the innovation performance issue in SMEs in Jordan. This section will go through the most important discussions and highlighted the findings of the study.

\section{The Existence of Innovation Performance Issue in The SMEs Industry in Jordan}

According to the researches that have been held on the SMEs in Jordan, there is a lack of efficiency, productivity, and effectiveness in the practices of the Jordanian SMEs (Al Tawara \& Gide, 2017), while the Jordanian government requires the SMEs to contribute further in the development of the Jordanian economy (Betz \& Frewer, 2016). The researcher found through the previous literature and government reports that the SMEs is not reaching the global level of innovation and creativity, and keep doing the traditional business practices. Moreover, the SMEs in Jordan are not aware of the turn of these firms in handling the economy of a country with such citizens number. The research found that the Jordanian economy in the current economic situation in the world, especially in the surrounding countries could role the economic situation in the country and the middle east overall. In the previous literature, the researcher stated the importance and capacity of SMEs in the economy nowadays globally, which is also supposed to be implemented and well-used in Jordan.

\section{The Importance of HRM and KM on Practicing Innovation Performance in SMEs in Jordan}

According to the previous literature and reports, the researcher found that there is an important role of HRM on intellectual capital, creativity, and innovativeness of the SMEs in Jordan (Khudeir, 2016). There is a knowledgeable human resource in Jordan but it is not exploited and well-invested in enriching the creativity and innovativeness of the firms (Alshanty et al., 2019). This is impeding the development of the industry due to the strict and inflexible managerial patterns in the Jordanian SMEs. The industry needs skillful, experts and, knowledgeable staff to carry on the innovation performance and assist the country's economy. This study found through reviewing the literature that there is a crucial role of KM and HRM on innovation performance and also the main source and support to the individuals and firms to raise and innovate in their daily tasks. 


\section{The Importance of the Innovation Performance in Jordanian SMEs.}

The researcher found the previous researches discussed that the Jordanian government is reporting the need for the SMEs activation as the main sector. This could handle the employment percent, productivity, and financial support to the country (Al Tawara \& Gide, 2017). Thus, the implementation of the innovation performance could increase the SMEs in Jordan in the economic, practical, and theoretical base in the industry (Betz \& Frewer, 2016). Therefore, this study is encouraging the researchers to test several factors' impact on the performance of the SMEs in Jordan to establish a framework to be implemented in the Jordanian industry.

\section{CONCLUSION}

The researchers reviewed several relevant studies on the SMEs in Jordan and the effect of innovation performance, creativity, HRM, and KM on the practices of these firms, as well as how it could impact the economics of the country. The findings of this study embodied the importance of activating the role of the SMEs in Jordan through implanting the keys of the innovation performance in the firms. HRM and KM are found to be the most important factors in the country in which it needs to create a suitable creative environment to enable the industry to achieve innovation performance and contribute to the development of the country's economy. This study's practical implications could be reflected in the innovation performance level and improving the human resource abilities and skills in Jordan and enhance the knowledge base in the country. Meanwhile, the theoretical implications could be the aggregation and ideas of the researcher about the optimal framework to be implemented in the country.

\section{REFERENCES}

Acs, Z. J., \& Audretsch, D. B. (1987). Innovation in large and small firms. Economics letters, 23(1), 109-112.

Al Tawara, A., \& Gide, E. (2017). A Comprehensive Literature Review on the Adoption of Social Media Marketing in SME Retailors in Jordan. International Journal of Business and Management Studies, ISSN, 2158-1479.

Al-Dwairi, R. M., Al-Tweit, N., \&Zyout, K. (2018, April). Factors influencing cloud-computing adoption in small and medium ecommerce enterprises in Jordan. In Proceedings of the 2018 International Conference on Internet and e-Business (pp. 73-78).

Al-Hyari, K. (2013). Identification of barrier factors and potential solutions to SMEs development among Jordanian manufacturing sector. International Journal of Business and Management, 8(24), 132.

Alshanty, A., Emeagwali, O., Ibrahim, B., \&Alrwashdeh, M. (2019). The effect of market-sensing capability on knowledge creation process and innovation Evidence from SMEs in Jordan. Management Science Letters, 9(5), 727-736.

Anthony, Scott D.; Johnson, Mark W.; Sinfield, Joseph V.; Altman, Elizabeth J. (2008). Innovator's Guide to Growth. "Putting Disruptive Innovation to Work". Harvard Business School Press

Armstrong, M., \& Taylor, S. (2020). Armstrong's handbook of human resource management practice. Kogan Page Publishers.

Assaad, R., \& Amer, M. (2008). Labor Market Conditions in Jordan 1995-2006: An Analysis of Microdata Sources. Amman, Jordan: Al-Manar, National Center for Human Resouce Development.

Assaad, R., Krafft, C., \&Keo, C. (2018a). The Composition of Labor Supply and Its Evolution from 2010 to 2016 in Jordan (Economic Research Forum Working Paper No. 1183).

Assaad, R., Salemi, C., \&Assaad, R. (2018b, November). The Structure of Employment and Job Creation in Jordan: 2010-2016. In Economic Research Forum Working Paper Series (Forthcoming). Cairo, Egypt.

Azar, G., \&Ciabuschi, F. (2017). Organizational innovation, technological innovation, and export performance: The effects of innovation radicalness and extensiveness. International Business Review, 26(2), 324-336.

Baccarella, A., Williams, C. R., Parrish, J. Z., \& Kim, C. C. (2018). Empirical assessment of the impact of sample number and read depth on RNA-Seq analysis workflow performance. BMC bioinformatics, 19(1), 423.

Berger, C. R. (2015). Knowledge structures and social interaction. The International Encyclopedia of Interpersonal Communication, 1-14.

Betz, F., \&Frewer, G. (2016). Neighbourhood SME financing: Jordan. Regional Studies and Roundtables.

Bocken, N., Boons, F., \&Baldassarre, B. (2019). Sustainable business model experimentation by understanding ecologies of business models. Journal of Cleaner Production, 208, 1498-1512.

Bromiley, P., \& Rau, D. (2016). Operations management and the resource based view: Another view. Journal of Operations Management, 41, 95-106.

Campbell, J. M., \& Park, J. (2017). Extending the resource-based view: Effects of strategic orientation toward community on small business performance. Journal of Retailing and Consumer Services, 34, 302-308.

Camra-Fierro, J., Centeno, E., Al-Hyari, K., Al-Weshah, G., \&Alnsour, M. (2012). Barriers to internationalisation in SMEs: evidence from Jordan. Marketing Intelligence \& Planning.

Chang, E., \& Chin, H. (2018). Signaling or experiencing: Commitment HRM effects on recruitment and employees' online ratings. Journal of Business Research, 84, 175-185.

Comunian, R., Gilmore, A., \& Jacobi, S. (2015). Higher education and the creative economy: Creative graduates, knowledge transfer and regional impact debates. Geography Compass, 9(7), 371-383.

Crespi, G., Tacsir, E., \& Zuniga, P. (2011, September). Financial Constraints and innovation investment in Latin America: Evidence from Argentina, Chile and Uruguay. Georgia Institute of Technology.

Demircioglu, M. A. (2017). Reinventing the wheel? Public sector innovation in the age of governance. Public Administration Review, 77(5), 800-805.

Diaz-Fernandez, M., Pasamar-Reyes, S., \& Valle-Cabrera, R. (2017). Human capital and human resource management to achieve ambidextrous learning: A structural perspective. BRQ Business Research Quarterly, 20(1), 63-77.

Ferraris, A., Santoro, G., \&Dezi, L. (2017). How MNC's subsidiaries may improve their innovative performance? The role of external sources and knowledge management capabilities. Journal of Knowledge Management.

Franceschini, S., Faria, L. G., \& Jurowetzki, R. (2016). Unveiling scientific communities about sustainability and innovation. A 
bibliometric journey around sustainable terms. Journal of Cleaner Production, 127, 72-83.

Frederiksen, M. H., \& Knudsen, M. P. (2017). From creative ideas to innovation performance: The role of assessment criteria. Creativity and Innovation Management, 26(1), 60-74.

Grimpe, C., Sofka, W., Bhargava, M., \& Chatterjee, R. (2017). R\&D, marketing innovation, and new product performance: a mixed methods study. Journal of Product Innovation Management, 34(3), 360-383.

Habib, S., Zahra, F., \& Mushtaq, H. (2015). Impact of training and development on employees' performance and Productivity: a case study of Pakistan. European Journal of Business and Social Sciences, 4(08), 326-330.

Hajir, J. A., Obeidat, B. Y., Al-dalahmeh, M. A., \&Masa'deh, R. (2015). The role of knowledge management infrastructure in enhancing innovation at mobile telecommunication companies in Jordan. European Journal of Social Sciences, 50(3), 313-330.

Hassan, P. T. R., \& Hussein, A. K. A. (2019). The contribution of the mental motivation in knowledge achievement of some basic skills in volleyball for the students of the second stage in the college of physical education and sports sciences University of Diyala. journal mustansiriyah of spors science, 1(2), 280-298.

Henriksen, D. (2019). Expanding the paradigm: Bringing designerly perspectives into creativity scholarship. Creativity Studies, 12(1), 15-33.

Hisschemöller, M., Hoppe, R., Dunn, W. N., \&Ravetz, J. R. (2018). Knowledge, power, and participation in environmental policy analysis: an introduction. In Knowledge, power, and participation in environmental policy analysis (pp. 1-26). Routledge.

Hoffman, K., Parejo, M., Bessant, J., \& Perren, L. (1998). Small firms, R\&D, technology and innovation in the UK: a literature review. Technovation, 18(1), 39-55.

Jiménez, A., \& Zheng, Y. (2018). Tech hubs, innovation and development. Information Technology for Development, 24(1), 95-118.

Kearney, C., \&Hisrich, R. D. (2014). Entrepreneurship in developing economies: transformation, barriers and infrastructure. In Necessity Entrepreneurs. Edward Elgar Publishing.

Khalili, A. (2016). Linking transformational leadership, creativity, innovation, and innovation-supportive climate. Management Decision.

Khudeir, H. (2016). The Effect of Blending HRM Transformational Leadership Style with HRM ICT Expertise Leadership Style on Creating New HRM Strategy That Enable National Companies to Go Global. Evidence from Jordan: Sayegh Group and Hikma Pharmaceutical Corporation. Journal of Education and Practice, 7(31), 108-112.

Lai, H. M., Chen, C. P., \& Chang, Y. F. (2014). Determinants of knowledge seeking in professional virtual communities. Behaviour\& Information Technology, 33(5), 522-535.

Li, J., \& Chen, J. (2006). Development of Chinese small and medium-sized enterprises. Journal of small business and enterprise development.

Liu, Q., \& Lu, R. (2016). On-the-job training and productivity: Firm-level evidence from a large developing country. China Economic Review, 40, 254-264.

Malik, G., McKenna, L., \& Plummer, V. (2015). Perceived knowledge, skills, attitude and contextual factors affecting evidence-based practice among nurse educators, clinical coaches and nurse specialists. International journal of nursing practice, 21, 46-57.

Malkawi, M., \& Abu, R. A. (2016). Knowledge Management Capabilities and its impact on Organizational Creativity in SME's. In Innovation Arabia conference congress proceeding, HBMSU, Dubai.

Mardani, A., Nikoosokhan, S., Moradi, M., \&Doustar, M. (2018). The relationship between knowledge management and innovation performance. The Journal of High Technology Management Research, 29(1), 12-26.

Melhem, I. I. A. B. (2019). The Mediating Effect of Job Satisfaction on the Relationship Between Belongingness and Challenging Work Towards Employee Retention (Doctoral dissertation, UniversitiSains Islam Malaysia).

Mellander, C.; Florida, R. (2011). Creativity, talent and regional wages in Sweden. In: The Annals of Regional Science, 46(3):637660.

Migdadi, M. M., Zaid, M. K. A., Yousif, M., Almestarihi, R. D., \& Al-Hyari, K. (2017). An empirical examination of knowledge management processes and market orientation, innovation capability, and organisational performance: Insights from Jordan. Journal of Information \& Knowledge Management, 16(01), 1750002.

Mohammed, M. A., \&Hassanain, M. A. (2010). Towards improvement in facilities operation and maintenance through feedback to the design team. The Built \& Human Environment Review, 3, 72-87.

Monavvarian, A., \& Khamda, Z. (2010). Towards successful knowledge management: people development approach. Business Strategy Series.

Njoku, E., Ruël, H., Rowlands, H., Evans, L., \& Murdoch, M. (2019). An analysis of the contribution of e-HRM to sustaining business performance. In HRM 4.0 For Human-Centered Organizations. Emerald Publishing Limited.

Noe, R. A., Hollenbeck, J. R., Gerhart, B., \& Wright, P. M. (2017). Human resource management: Gaining a competitive advantage. New York, NY: McGraw-Hill Education.

Papa, A., Dezi, L., Gregori, G. L., Mueller, J., \&Miglietta, N. (2018). Improving innovation performance through knowledge acquisition: the moderating role of employee retention and human resource management practices. Journal of Knowledge Management.

Paula, J. T., Aguiar, A. C., Sousa, I. M., Magalhaes, P. M., Foglio, M. A., \& Cabral, F. A. (2016). Scale-up study of supercritical fluid extraction process for Baccharisdracunculifolia. The Journal of Supercritical Fluids, 107, 219-225.

Roman, N. A. (2017). A Comprehensive Review of E-HRM in Service SMEs in Jordan. International Business Research, 10(5), 116120.

Sadler-Smith, E. (2015). Wallas' four-stage model of the creative process: More than meets the eye?. Creativity Research Journal, 27(4), 342-352.

Saether, E. A. (2019). Motivational antecedents to high-tech R\&D employees' innovative work behavior: Self-determined motivation, person-organization fit, organization support of creativity, and pay justice. The Journal of High Technology Management Research, 30(2), 100350.

Santos, G., Afonseca, J., Lopes, N., Félix, M. J., \&Murmura, F. (2018). Critical success factors in the management of ideas as an essential component of innovation and business excellence. International Journal of Quality and Service Sciences, 10(3), 214232.

Shin, S. J., Jeong, I., \& Bae, J. (2018). Do high-involvement HRM practices matter for worker creativity? A cross-level approach. The International Journal of Human Resource Management, 29(2), 260-285. 
Shujahat, M., Sousa, M. J., Hussain, S., Nawaz, F., Wang, M., \&Umer, M. (2019). Translating the impact of knowledge management processes into knowledge-based innovation: The neglected and mediating role of knowledge-worker productivity. Journal of Business Research, 94, 442-450

Soto-Acosta, P., Popa, S., \& Palacios-Marqués, D. (2017). Social web knowledge sharing and innovation performance in knowledgeintensive manufacturing SMEs. The Journal of Technology Transfer, 42(2), 425-440.

Subramaniam, B., Selvanayagam, J., \&Yogarajah, V. (2016). Impact of Recruitment and Selection, Training and Development, Performance Evaluation, and Compensation (HRM Practices) on Employees' Trust.

Tidd, J., \& Bessant, J. R. (2018). Managing innovation: integrating technological, market and organizational change. John Wiley \& Sons.

Tubbs, S.L. \& Moss, S. (2002). Human Communication, Principles and Contexts. Boston, McGrawHill.

Vaziri, S., \& Farhadi, M. A. (2018). Impact of knowledge-based human resource management policies on innovation performance and intellectual capital (Case Study: National Oil Products Distribution Company-Golestan Region).

Wikhamn, W. (2019). Innovation, sustainable HRM and customer satisfaction. International Journal of Hospitality Management, 76, 102-110.

\section{AUTHORS' BIOGRAPHY}

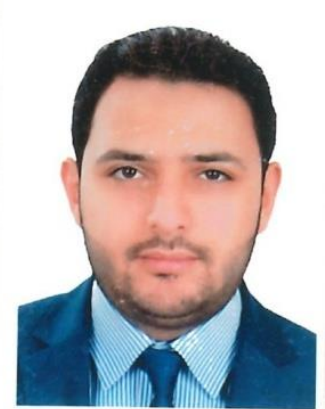

Ahmed is currently a PhD student at Graduate School of Business, Universiti Sains Malaysia. He has obtained MBA at Middle East University in 2017 and Bachelor of Computer Information Systems in 2015. He has published three papers in Scopus-indexed journals and a conference paper.

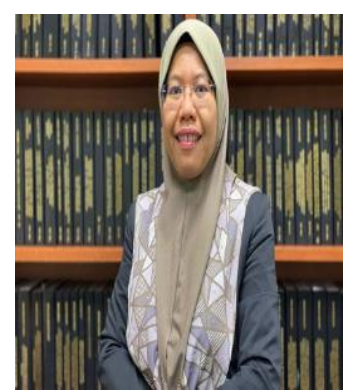

Dr. Norfarah Nordin is a Senior Lecturer at the Graduate School of Business, Universiti Sains Malaysia. Her research has focused on the area of entrepreneurs' behavior and Small-Medium-Enterprise. Her current research focuses on social media usage for business decision-making, business analytics, and entrepreneurship. 